\title{
How Are Our Future Agriculture and Natural Resources Projected under Varying Climate?'
}

\author{
Young Gu Her, Ashley Smyth, Zachary Brym, and Elias Bassil²
}

\section{Introduction}

Global climate changes are likely to affect Florida's agriculture and natural resources by increasing air temperature and thus altering the frequency and severity of rainfall and drought events (Chassignet et al. 2017; Song et al. 2020). In Florida, citrus production is expected to migrate north due to projected warming (Rosenzweig et al. 1996; Tubiello et al. 2002). In oceans, rising water temperature can increasingly drive harmful algal blooms and damage coral reefs (often called coral bleaching), while mangrove forests could shift north into more temperate salt marshes (Bauman et al. 2010; Wells et al. 2015; Simpson et al. 2017). In addition, expected air temperature increases can create more intense and longer drought events, which lead to increased competing demands for freshwater that require more intensive water resource management. Whether the climate cools or warms, both of which have occurred in the past, its change will affect future agriculture and natural resources sooner rather than later. Therefore, it is essential to understand what the future climate may be like, in order to anticipate and better prepare for adverse effects. A companion EDIS publication (How Is Our Future Climate Projected?) describes how future climate could be estimated or projected. This article explains how agriculture and natural resources may respond to projected future climate and how climate projections can be useful in developing management plans for the improved sustainability of Florida's agriculture and natural resources. This article aims to help increase the public awareness of climate change impacts on Florida and improve understanding of the connections among climate, agriculture, and natural resources.

\section{Freshwater Resources}

Freshwater resources are critical to ecosystems. The quality of our life depends on the amount and quality of freshwater we can use every day. The water cycle is a dynamic, complicated, and delicate balance of precipitation and evapotranspiration (ET), and small changes in climate may permanently alter the landscape. Changes in air temperature and, rainfall amount, intensity, and frequency will directly affect the amount of freshwater available for drinking water, irrigation, and hydropower as well as the frequency and severity of extreme events such as flood, drought, and water quality issues (Kundzewicz et al. 2008; Coffey et al. 2019; Paul et al. 2019).

Climate models agree with increases in future air temperature, but precipitation is not consistently projected (Song et al. 2020). Such inconsistency is attributed to the complexity associated with the mechanisms controlling precipitation events and the limitations of existing models. Climate model projections have suggested that total rainfall amounts can either decrease or increase with climate change in Florida, depending on specific locations and

1. This document is AE545, one of a series of the Department of Agricultural and Biological Engineering, UF/IFAS Extension. Original publication date September 2020. Visit the EDIS website at https://edis.ifas.ufl.edu for the currently supported version of this publication.

2. Young Gu Her, assistant professor, Department of Agricultural and Biological Engineering; Ashley Smyth, assistant professor, Department of Soil and Water Sciences; Zachary Brym, assistant professor, Agronomy Department; and Elias Bassil, assistant professor, Horticultural Sciences Department; UF/ IFAS Tropical Research and Education Center, Homestead, FL 33031.

The Institute of Food and Agricultural Sciences (IFAS) is an Equal Opportunity Institution authorized to provide research, educational information and other services

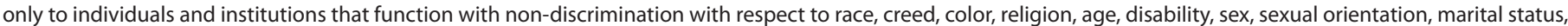

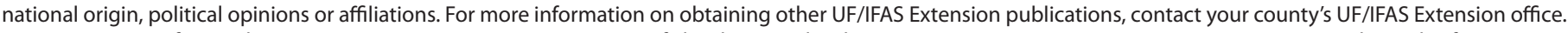
U.S. Department of Agriculture, UF/IFAS Extension Service, University of Florida, IFAS, Florida A \& M University Cooperative Extension Program, and Boards of County Commissioners Cooperating. Nick T. Place, dean for UF/IFAS Extension. 
seasons (Biasutti et al. 2012; Todd et al. 2012; Obeysekera et al. 2017; Infanti et al. 2019; Song et al. 2020). Lower total rainfall amount and frequency with higher intensity will translate into lower recharge of water supplies and therefore fewer available water resources. In addition, lower rainfall will result in greater needs of remote water supplies, depending on the distribution of rainfall events. The intensity of rainfall events is projected to increase across Florida with great spatial variability (Wang et al. 2013). The increased intensity of storm events would require more water infrastructure and associated construction and maintenance costs. Rainfall that occurs with greater intensity will also result in less total effective rainfall for use by crops because of the low water-holding capacity of many Florida soils. This, in turn, will lead to greater irrigation needs to maintain crops under current farming practices. Furthermore, agricultural water demand increases due to a warmer and drier climate will compete with other water resources, such as those used for drinking water (EPA 1997).

While changes in rainfall have a direct impact on water availability, changes in temperature and subsequent ET also influence water supply demands. Climate change models have projected increases in annual atmospheric ET demand of 70 to $130 \mathrm{~mm}$ (2.76 to 5.12 inches) by 2050 in south Florida (Obeysekera et al. 2011). The projected higher atmospheric ET demand for future climate scenarios would translate into greater crop water needs for irrigation under current farming conditions and practices. The potential changes related to ET, such as temperature and solar radiation, could have other effects on agricultural production and thus irrigation. For example, temperature changes will influence the timing and rate of crop development. The shifting of a crop season and harvest would create additional irrigation modifications, which could be either an increase or a decrease, depending on timing.

Another concern with climate change is the quality of water. Sea-level rise will increase the risk of saltwater intrusion into aquifers (Karl 2009) and raise the possibility that seawater could inundate areas further inland during storms. Therefore, some groundwater wells used for municipal water and irrigation may no longer be viable as freshwater supplies. Salinity contamination has already become an issue in south Florida (Miami-Dade Office of Resilience 2016; Hughes and White 2014). The City of Hallandale Beach, located in Broward County, has lost six of eight freshwater wells to saltwater intrusion (Hallandale Beach, Green Initiatives 2018). Alternative water sources or water treatment will be needed in areas where salinity concentrations exceed the level that is considered safe for infrastructure, drinking water, and crops. In addition, an increased prevalence of saline irrigation water and saline soils would require a shift in farming practices. For example, irrigation with high-quality, low-salinity irrigation water would be required to flush the soil profile of salt buildup if irrigation with salty water is used excessively. A shift toward growing more salt-tolerant varieties or new, more salt-tolerant crop is also likely, depending on the levels of soil and water salinity and other agricultural constraints. Increased rainfall intensity will accelerate soil erosion and pollutant loading from natural and agricultural areas to downstream waterbodies, creating water quality issues such as algal blooms. Longer dry periods and stronger storm events will also increase runoff of urban pollutants, leading to increased costs for urban water drainage containment and treatment.

Increased air temperature will accelerate evapotranspiration and thus make the Earth's surface drier in some areas, while the added moisture to the air will create excess precipitation in others. The complicated hydrological consequences of changing climate would challenge water resources managers to handle increased needs of clean freshwater. Climate models enable scientists to figure out how the future climate may look and engineers to consider projected changes in water resources management planning. Such efforts help the water infrastructure, including canals, dams, levees, stormwater drainage and sewer systems, and irrigation networks, to be appropriately designed to protect our society from the changes and to eventually improve its sustainability.

\section{Plants and Crops}

Farmers plan their farm operations based on a detailed sense of climate-related phenomena, such as transitions between seasons and weather events including freeze, flooding, or drought, that can impact crop production. Farmers also manage for day-to-day weather changes to mitigate the impact on crops. Weather system technologies (Florida Automated Weather Network 2018) and irrigation schedulers are available to help farmers with day-to-day management decisions. With a focused understanding of local environmental conditions on daily management decisions, the distinction between climate and weather can be challenging. Modern innovations in farm management are shifting responsiveness to climatic trends from the intuitive observation by the farmer to the technological on-farm and regional collection of information (AgroClimate: http:// agroclimate.org/). The adoption of weather and climatemonitoring technologies is becoming a driving force for agricultural decision-making. 
One commonly understood product of a climate model is the Plant Hardiness Zones (USDA 2012). There are visible shifts in the hardiness zones for the United States, just in the last 25 years (Figure 1) (Arbor Day Foundation 2018). These hardiness zones represent the ranges of average annual minimum winter temperature across the United States and are used as an indication of suitable crops for a region.

The minimum annual winter temperature information defined on the Plant Hardiness Zone Map is one piece

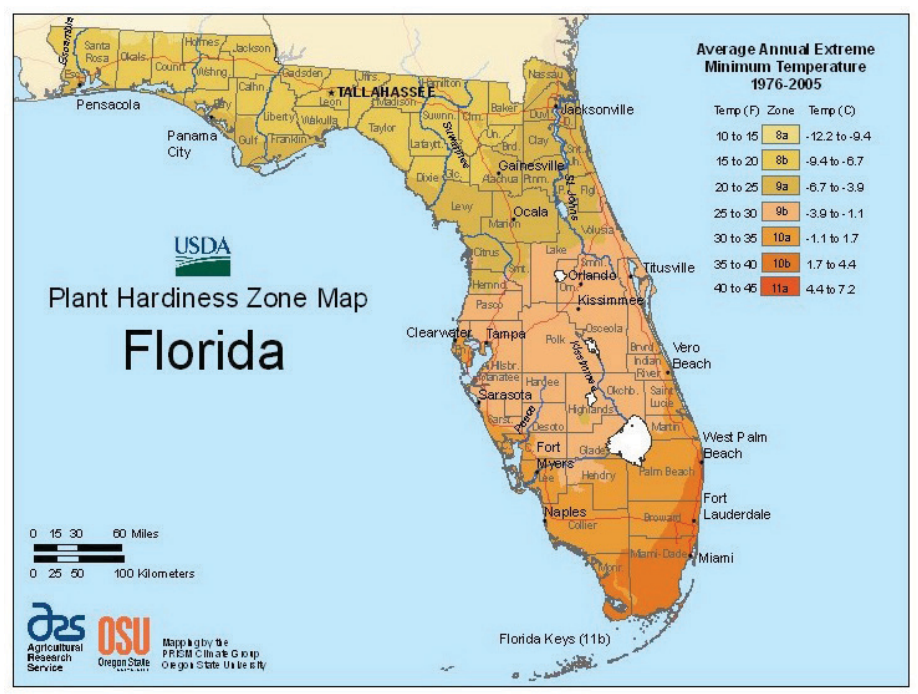

Figure 1. Florida Plant Hardiness Zone Map (USDA Plant Hardiness Zone Map, 2012: https://planthardiness.ars.usda.gov/PHZMWeb/). Credits: USDA

of related climate information affecting plant survival and production. Additional climatic information, such as maximum summer temperature, annual rainfall, and light availability, is also important for farmers who want to make crop selection and management decisions. Climate models and decision support tools would also be helpful in determining the "right plant, right place, right time" under altered future climate conditions. The greatest challenge to many cropping systems threatened by climate change may be a lack of the predictability needed to plan and manage cropping systems affected by short-term climate fluctuations. Long-term planning for the impacts of climate change in the future is critical for the adaptation and sustainability of cropping strategies. An ideal situation would be to develop resources capable of reporting realtime, regional climate-related information, and tools used by farmers to make management decisions important to maintaining crop productivity under climate change.

Climate prediction models can be useful to long-term management and cropping system planning decisions, for example, growers' long-term investment decisions, such as the planting of a fruit tree orchard. Climate prediction models can significantly benefit growers by helping to match cultivars or even crop species to specific climate characteristics of a region. A fruit tree orchard is a significant investment of time and resources. Given that some orchards do not become profitable until after 7 years and bear fruit for another 15 to 20 years, the consideration of future climate change becomes a valuable asset to current management decisions. Climate models may also aid in the management of biotic and abiotic stresses that could adversely affect cropping systems. For example, a certain incidence of disease or insect pest may become more prevalent in particular areas as a consequence of increased average temperatures and humidity (Kurukulasuriya and Rosenthal 2013; Walthall et al. 2013). A study demonstrated that warmer air temperatures would increase pest populations for crops including corn, potatoes, and wheat from historical data (Chen and McCarl 2001). Similarly, climate change projections, especially those associated with sea-level rise, can help predict areas where saline flooding events could become more common. Avocado, which is particularly sensitive to both flooding and salinity, is expected to suffer in areas where saline flooding may occur. Growers may find climate model information useful in planning new avocado orchards.

A significant challenge facing the plant science community is a general unavailability of crop cultivars adapted to abiotic stresses, such as periodic drought events, flooding, salinity, and nutritional imbalances brought about by the former. Modern plant breeding efforts of important food crop cultivars have focused on selecting for increased yield under ideal conditions (i.e., adequate irrigation, fertility in experimental sites with suitable climate) and have produced germplasm that is poorly adapted to altered climate conditions (Mickelbart et al. 2015). Consequently, genetic bottlenecks exist in many crops that result in varieties with little genetic adaptation to abiotic stresses brought about by climate change. Climate models can aid in better breeding strategies by informing growers of the potential incidence of climatic stresses and help breeders select for traits that would make crop cultivars better adapted to specific regions.

\section{Marine Resources}

Marine ecosystems are among the most ecologically and economically valuable areas on the planet. Globally, marine ecosystems contribute \$14 trillion (USD) worth of benefits to society each year (Costanza et al. 1997). In Florida, habitats such as oyster reefs, sand dunes, mangroves, seagrass beds, and salt marshes all provide benefits to people. A 3.6-mile $(5.8 \mathrm{~km})$ oyster reef in Florida 
provides $\$ 38,000$ to $\$ 46,000$ per year to enhanced fisheries production, and Florida mangroves provide $\$ 246$ per acre (\$608 per hectare) per year in water quality benefits (Blair et al. 2017). Nevertheless, climate change poses a threat to these systems. Models indicate that coastal and marine ecosystems will become warmer, saltier, and more acidic in the future as climate changes. These changes can affect the structure and function of marine ecosystems.

Climate models predict that there will be more extreme weather events in the future. Prolonged droughts followed by more intense storm events will lead to an increase in nutrient loading to the coast (Loecke et al. 2017), where nutrients like nitrogen and phosphorus fuel excess algal growth, resulting in eutrophication of water bodies (Conley et al. 2009; Havens and Frazer 2012). This will also affect the health of the Everglades. Additionally, changes in freshwater discharge can also change salinity. These climate-induced changes have consequences for the structure and function of Florida's freshwater and coastal ecosystems (Havens 2018; Havens 2012).

While extreme events, such as drought and floods, are expected to increase, there will also be dramatic swings between these two conditions (Swain et al. 2018). Climate models can be used to predict these swings and estimate the riverine nitrate load (Loeke et al. 2017). Changes in precipitation derived from climate models indicate that eutrophication of coastal waterbodies will increase (Sinha et al. 2017). Excess nitrogen is considered a pollutant to coastal waterbodies and is linked to dead zones and algal blooms. In Florida, excess nutrients have been linked to the decline in seagrass in the Indian River Lagoon and the decline of seagrasses and coral reefs in the Florida Keys (Lapointe and Clark 1992; Lapointe et al. 2020). In addition to changes in precipitation, the decrease in freshwater flow to the coast can allow saltwater to move inland, resulting in saltwater intrusion. The increase in saltwater can cause desorption of sediment-bound phosphorus, leading to an increase in the availability of phosphorus in coastal waters (Flower et al. 2017). Climate models can be used to improve our understanding of how precipitation and sea-level rise affect nutrients, coastal water quality, and coastal ecosystems. Ultimately, information obtained from climate models can be incorporated into conservation plans that will help to limit the amount of nutrients that enter coastal systems.

Changes in climate will affect coastal and marine water quality by changing dissolved oxygen and nutrients. As surface temperatures increase, water will hold less oxygen, leading to more areas of low oxygen. At the same time, warmer water will increase the metabolism of marine organisms, raising their demand for oxygen (Schulte 2015). These combined effects will cause dead zones to expand and persist (Altieri and Gedan 2014). The increase in runoff and warmer temperatures can also increase stratification in the water column, resulting in more areas of low oxygen near the bottom. This stratification can lead to fish kills. While changing climate can affect marine ecosystems, projections of more intense tropical storms and lower runoff would act to decrease stratification in the water column, lessening the effect of dead zones.

Climate models also suggest that ocean circulation will slow down in the Atlantic Ocean (Sévellec et al. 2017). Ocean currents move warm water from the tropics north. The warm water cools down as it moves north and sinks to the bottom because cold water is denser than warm water. However, the increase in freshwater entering the ocean that is associated with ice melt is causing ocean currents to slow down (Rahmstorf et al. 2015). Altered ocean currents can change connectivity and temperature regimes in coastal areas. This can impact the availability of food for marine organisms and also the dispersal of larvae. Other consequences of the altered ocean currents are related to the projections that northern areas will become cooler while the tropics will get warmer with more rainfall. The warmer temperatures can impact fisheries and marine resources and have already been associated with the collapse of fisheries (Pershing et al. 2015). The warming ocean also causes thermal stress to corals, leading to mass coral bleaching events and increases in coral disease outbreaks (Lesser 1997; Bruno et al. 2007).

Current models indicate that sea-levels will rise. The increase in sea-level means that the saltwater will move further upstream, moving the locations of the freshwater and saltwater transition zones further inland. This increase in surface water salinity can stress organisms that are accustomed to more brackish or freshwater environments. For example, elevated salinity in estuaries and coastal areas increases the chance of oysters becoming infected with a type of parasite, Minchinia (or Haplosporidium) nelsoni (MSX), leading to death of young oysters (Paraso et al. 1999). Sea-level rise directly threatens the stability of coastal ecosystems in Florida. Sea-level rise and saltwater intrusion in the Florida Everglades are causing sawgrass marshes to collapse (Wilson et al. 2018) and mangroves to retreat northward and landward (Meeder and Parkinson 2017). Sea-level rise creates a stressful environment for corals through increased wave stress, decreased calcification 
rates, and increased sedimentation rates (Smith and Buddemeier 1992).

Climate models are also used to inform our understanding of ways the $\mathrm{pH}$ of the ocean may change as atmospheric $\mathrm{CO}_{2}$ increases. Waves, wind, and turbulence in the ocean cause the ocean water to absorb $\mathrm{CO}_{2}$ in the air. Currents in the ocean then act to pump the $\mathrm{CO}_{2}$ to deeper water where it can be stored. Unfortunately, the increase in $\mathrm{CO}_{2}$ in the ocean can decrease the $\mathrm{pH}$ of the water, leading to more acidic conditions. Model simulations have been used to determine how changes in $\mathrm{CO}_{2}$ emissions will affect the $\mathrm{pH}$ of the ocean (Caldeira and Wickett 2003). The expected changes in $\mathrm{pH}$ can affect the formation of shells and skeletons for calcifying organisms like oysters and corals.

While climate models are helping scientists and managers identify areas at risk, combining historical data with climate models can help identify potential areas of climate refugia (Ban et al. 2016). Climate refugia in the ocean are identified as areas where biodiversity can persist or expand under changing climate conditions. Climate models have been used to identify locations that might escape the worst of climate change. This information can be used in conservation and management (Beyer et al. 2018). By combining climate models and satellite data, scientists are able to identify marine climate refugia. This information is being used in the development of marine protected areas and other management decisions that will increase the resilience of coastal ecosystems to climate change (Darling and Cote 2018).

\section{Summary}

Changing climate will affect everything on the Earth's surface, including agriculture and natural resources. Farming, freshwater, and saltwater systems are interacting with each other in complicated ways. The interaction may respond to projected climate changes in highly nonlinear manners with feedback creating emergent outcomes, all of which makes it difficult to precisely project the responses of the whole system. This article demonstrates the extent to which Florida agriculture and natural resources are affected by climate and weather patterns. The sustainability of our society requires development and implementation of plans and practices that help us to mitigate, adapt to, or even avoid the negative effects of climate change. Such efforts depend on understanding and quantifying expected impacts. This article speculates how projected future climate changes may influence Florida's agriculture and natural resources and discusses how climate modeling and projections help scientists and engineers to manage them in a sustainable way. Such information will facilitate communication and discussion on climate change impacts on Florida agriculture and natural resources. A companion EDIS publication, How Is Our Future Climate Projected?, explains the latest research and scientific terms for future climate projection.

\section{References}

Altieri, A. H., and K. B. Gedan. 2014. "Climate Change and Dead Zones.” Global Change Biology 21: 1395-1406.

Arbor Day Foundation. 2018. "Differences between 1990 USDA Hardiness Zones and 2015 Arborday.org Hardiness Zones." https://www.arborday.org/media/map_change.cfm

Ban, S. S., H. M. Alidina, T. A. Okey, R. M. Gregg, and N. C. Ban. 2016. "Identifying Potential Marine Climate Change Refugia: A Case Study in Canada's Pacific Marine Ecosystems." Global Ecology and Conservation 8: 41-54.

Bauman, A. G., J. A. Burt, D. A. Feary, E. Marquis, and P. Usseglio. 2010. “Tropical Harmful Algal Blooms: An Emerging Threat to Coral Reef Communities?” Marine Pollution Bulletin 60 (11): 2117-2122.

Beyer, H. L., E. V. Kennedy, M. Beger, C. A. Chen, J. E. Cinner, E. S. Darling, C. M. Eakin, et al. 2018. "Risk-Sensitive Planning for Conserving Coral Reefs under Rapid Climate Change." Conservation Letters 109: e12587-10.

Biasutti, M., A. H. Sobel, S. J. Camargo, and T. T. Creyts. 2012. "Projected Changes in the Physical Climate of the Gulf Coast and Caribbean." Climatic Change 112: 819-845.

Blair, S., C. Adams, T. Ankerson, M. McGuire, and D. Kaplan. 2015. Ecosystem Services Valuation for Estuarine and Coastal Restoration in Florida. TP-204. Gainesville: University of Florida Institute of Food and Agricultural Sciences. https://edis.ifas.ufl.edu/sg134

Bruno, J. F., E. R. Selig, K. S. Casey, C. A. Page, B. L. Willis, C. D. Harvell, H. Sweatman, and A. M. Melendy. 2007. "Thermal Stress and Coral Cover as Drivers of Coral Disease Outbreaks." PLOS Biology 5(6): e124. https://doi. org/10.1371/journal.pbio.0050124

Caldeira, K., and M. E. Wickett. 2003. "Anthropogenic Carbon and Ocean pH." Nature 425: 365. 
Chassignet, E. P., J. W. Jones, V. Misra, and J. Obeysekera (Eds.). 2017. Florida's Climate: Changes, Variations, \& Impacts. Gainesville, FL: Florida Climate Institute. https:// doi.org/10.17125/fci2017

Chen, C. C., and B. A. McCarl. 2001. "An Investigation of the Relationship between Pesticide Usage and Climate Change." Climatic Change 50 (4): 475-487.

Coffey, R., M. J. Paul, J. Stamp, A. Hamilton, and T. Johnson. 2019. "A Review of Water Quality Responses to Air Temperature and Precipitation Changes 2: Nutrients, Algal Blooms, Sediment, Pathogens." Journal of the American Water Resources Association 55 (4): 844-868.

Conley, D. J., H. W. Paerl, R. W. Howarth, D. F. Boesch, S. P. Seitzinger, K. E. Havens, C. Lancelot, and G. E. Likens. 2009. "Controlling Eutrophication: Nitrogen and Phosphorus." Science 323 (5917): 1014-1015. DOI: 10.1126/ science.1167755.

Costanza, R., R. d'Arge, R. De Groot, S. Farber, and M. Grasso. 1997. "The Value of the World's Ecosystem Services and Natural Capital.” Nature: 253-260.

Darling, E. S., and I. Cote. 2018. "Seeking Resilience in Marine Ecosystems.” Science 359: 986-987.

EPA. 1997. "Climate Change and Florida." Accessed on August 20, 2020. https://nepis.epa.gov/Exe/ZyPDF. cgi/40000IY6.PDF?.Dockey=40000IY6.PDF

Florida Automated Weather Network. 2018. "FAWN Irrigation Toolkit." https://fawn.ifas.ufl.edu/tools/scheduler/ irrigation_scheduler.php

Flower, H., M. Rains, D. Lewis, J. Zhang, and R. Price. 2017. "Saltwater Intrusion as Potential Driver of Phosphorus Release from Limestone Bedrock in a Coastal Aquifer." Estuarine, Coastal and Shelf Science 184: 166-176. https:// dx.doi.org/10.1016/j.ecss.2016.11.013

Havens, K. 2012. Effects of Climate Change on the Eutrophication of Lakes and Estuaries. SGEF-189. Gainesville: University of Florida Institute of Food and Agricultural Sciences. https://edis.ifas.ufl.edu/sg127

Havens, K. 2017. Climate Change: Effects on Salinity in Florida's Estuaries and Responses of Oysters, Seagrass, and Other Animal and Plant Life. SGEF-218. Gainesville: University of Florida Institute of Food and Agricultural Sciences. https://edis.ifas.ufl.edu/sg138
Havens, K., and T. Frazer. 2012. Rethinking the Role of Nitrogen and Phosphorus in the Eutrophication of Aquatic Ecosystems. SGEF190. Gainesville: University of Florida Institute of Food and Agricultural Sciences. https://edis.ifas. ufl.edu/sg118

Hughes, J. D., and J. T. White. 2014. "Hydrologic Conditions in Urban Miami-Dade County, Florida, and the Effect of Groundwater Pumpage and Increased Sea-level on Canal Leakage and Regional Groundwater Flow (No. 2014-5162)." US Geological Survey. https://pubs.usgs.gov/sir/2014/5162/ pdf/sir2014-5162.pdf

Infanti, J. M., B. P. Kirtman, N. G. Aumen, J. Stamm, and C. Polsky. 2019. "Assessment of Uncertainty in Multi-model Means of Downscaled South Florida Precipitation for Projected (2019-2099) Climate." International Journal of Climatology. https://doi.org/10.1002/joc.6365

Karl, T. R. 2009. Global Climate Change Impacts in the United States. Cambridge, UK: Cambridge University Press.

Kundzewicz, Z. W., L. J. Mata, N. W. Arnell, P. Döll, B. Jimenez, K. Miller, T. Oki, Z. Şen, and I. Shiklomanov. 2008. "The Implications of Projected Climate Change for Freshwater Resources and Their Management.” Hydrological Sciences Journal 53(1): 3-10.

Kurukulasuriya, P., and S. Rosenthal. 2013. "Climate Change and Agriculture: A Review of Impacts and Adaptations." Paper No. 91. The World Bank.

Lapointe, B. E., L. W. Herren, R. A. Brewton, and P. K. Alderman. 2020. "Nutrient Over-enrichment and Light Limitation of Seagrass Communities in the Indian River Lagoon, an Urbanized Subtropical Estuary." Science of the Total Environment 699: 134068.

Lapointe, B. E., and M. W. Clark. 1992. "Nutrient Inputs from the Watershed and Coastal Eutrophication in the Florida Keys." Estuaries 15: 465-13.

Lesser, M. P. 1997. "Oxidative Stress Causes Coral Bleaching during Exposure to Elevated Temperatures." Coral Reefs 16: 187-192.

Loecke, T. D., A. J. Burgin, D. A. Riveros-Iregui, A. S. Ward, S. A. Thomas, C. A. Davis, and M. A. S. Clair. 2017. "Weather Whiplash in Agricultural Regions Drives Deterioration of Water Quality." Biogeochemistry 133: 7-15. 
Meeder, J. F., and R. W. Parkinson. 2017. "SE Saline Everglades Transgressive Sedimentation in Response to Historic Acceleration in Sea-Level Rise: A Viable Marker for the Base of the Anthropocene?" Journal of Coastal Research 34 (2): 490-497.

Miami-Dade Office of Resilience. 2016. "Final Report for Resolution R-48-15 in Support of the Sea-level Rise Task Force Final Recommendation-Attachment 4: Report on Flooding and Saltwater Intrusion." https://www.miamidade. gov/green/library/sea-level-rise-flooding-saltwaterintrusion.pdf

Mickelbart, M. V., P. M. Hasegawa, and J. Bailey-Serres. 2015. "Genetic Mechanisms of Abiotic Stress Tolerance That Translate to Crop Yield Stability." Nature Reviews Genetics 16 (4): 237-251.

Obeysekera, J., W. Graham, M. C. Sukop, T. Asefa, D. Wang, K. Ghebremichael, and B. Mwashote. 2017. "Chapter 3: Implications of Climate Change on Florida's Water Resources." In Florida's Climate: Changes, Variations, \& Impacts. Gainesville, FL: Florida Climate Institute.

Obeysekera, J., J. Park, M. Irizarry-Ortiz, P. Trimble, J. Barnes, J. Vanarman, W. Said, and E. Gadzinski. 2011. Past and Projected Trends in Climate and Sea-level for South Florida. West Palm Beach, FL: South Florida Water Management District.

Paul, M. J., R. Coffey, J. Stamp, and T. Johnson. 2019. “A Review of Water Quality Responses to Air Temperature and Precipitation Changes 1: Flow, Water Temperature, Saltwater Intrusion." Journal of the American Water Resources Association 55 (4): 824-843.

Pershing, A. J., M. A. Alexander, C. M. Hernandez, L. A. Kerr, A. Le Bris, K. E. Mills, J. A. Nye, et al. 2015. "Slow Adaptation in the Face of Rapid Warming Leads to Collapse of the Gulf of Maine Cod Fishery." Science 350: 809.

Rahmstorf, S., J. E. Box, G. Feulner, M. E. Mann, A. Robinson, S. Rutherford, and E. J. Schaffernicht. 2015. "Exceptional Twentieth-Century Slowdown in Atlantic Ocean Overturning Circulation." Nature Climate Change 5: 475-480.

Rosenzweig, C., J. Phillips, R. Goldberg, J. Carroll, and T. Hodges. 1996. "Potential Impacts of Climate Change on Citrus and Potato Production in the US." Agricultural Systems 52 (4): 455-479.
Schulte, P. M. 2015. “The Effects of Temperature on Aerobic Metabolism: Towards a Mechanistic Understanding of the Responses of Ectotherms to a Changing Environment." Journal of Experimental Biology 218: 1856-1866.

Sévellec, F., A. V. Fedorov, and W. Liu. 2017. "Arctic Sea-Ice Decline Weakens the Atlantic Meridional Overturning Circulation." Nature Climate Change 7 (8): 604-610.

Simpson, L. T., T. Z. Osborne, L. J. Duckett, and I. C. Feller. 2017. "Carbon Storages along a Climate Induced Coastal Wetland Gradient.” Wetlands 1-13.

Sinha, E., A. M. Michalak, and V. Balaji. 2017. "Eutrophication Will Increase during the 21st Century as a Result of Precipitation Changes." Science 357: 405.

Smith, S. V., and R. W. Buddemeier. 1992. "Global Change and Coral Reef Ecosystems." Annual Review of Ecology and Systematics 23: 89-118. www.jstor.org/stable/2097283

Song, J., Y. Her, S. Shin, J. Cho, R. Paudel, Y. Khare, J. Obeysekera, and C. Martinez. 2020. "Evaluating the Performance of Climate Models in Reproducing the Hydrological Characteristics of Rainfall Events." Hydrological Sciences Journal. 65(9): 1490-1511 doi.org/10.1080/02626667.2020. 1750616

Swain, D. L., B. Langenbrunner, J. D. Neelin, and A. Hall. 2018. "Increasing Precipitation Volatility in Twenty-FirstCentury California.” Nature Publishing Group: 1-10.

Todd, M. J., R. Muneepeerakul, F. Miralles-Wilhelm, A. Rinaldo, and I. Rodriguez-Iturbe. 2012. "Possible Climate Change Impacts on the Hydrological and Vegetative Character of Everglades National Park, Florida." Ecohydrology 5: 326-336.

Tollefson, J. 2015. "UN Climate Reports Are Increasingly Unreadable." Nature News. https://www.nature.com/news/ un-climate-reports-are-increasingly-unreadable-1.18543

Tubiello, F. N., C. Rosenzweig, R. A. Goldberg, S. Jagtap, and J. W. Jones. 2002. "Effects of Climate Change on US Crop Production: Simulation Results Using Two Different GCM Scenarios. Part I: Wheat, Potato, Maize, and Citrus." Climate Research 20 (3): 259-270.

USDA. 2012. "USDA Plant Hardiness Zone Map." Accessed on August 20, 2020. https://planthardiness.ars.usda.gov 
Walthall, C. L., C. J. Anderson, L. H. Baumgard, E.

Takle, and L. Wright-Morton. 2013. "Climate Change and Agriculture in the United States: Effects and Adaptation."

https://lib.dr.iastate.edu/ge_at_reports/1/

Wang, D., S. C. Hagen, and K. Alizad. 2013. "Climate

Change Impact and Uncertainty Analysis of Extreme

Rainfall Events in the Apalachicola River Basin, Florida."

Journal of Hydrology 480: 125-135.

Wells, M. L., V. L. Trainer, T. J. Smayda, B. S. Karlson, C. G. Trick, R. M. Kudela, A. Ishikawa, et al. 2015. "Harmful Algal Blooms and Climate Change: Learning from the Past and Present to Forecast the Future." Harmful Algae 49:

68-93.

Wilson, B. J., S. Servais, S. P. Charles, S. E. Davis, E. E. Gaiser, J. S. Kominoski, J. H. Richards, and T. G. Troxler. 2018. "Declines in Plant Productivity Drive Carbon Loss from Brackish Coastal Wetland Mesocosms Exposed to Saltwater Intrusion." Estuaries and Coasts 41 (8):

2147-2158. 